\title{
Association af Changes in the Bacterial Ecology of Bovine Mastitis with Changes in the use of Milking Machines and Antibacterial Drugs
}

\author{
By V. Myllys, T. Honkanen-Buzalski, P. Huovinen, M. Sandholm and E. Nurmi
}

Department of Food Hygiene, National Veterinary and Food Research Institute, Department of Pharmacology and Texicology, College of Veterinary Medicine, Helsinki, and Antimicrobial Research Laboratory, National Public Health Institute, Turku, Finland.

\begin{abstract}
Myllys, V., T. Honkanen-Buzalski, P. Huovinen, M. Sandholm and E. Nurmi: Association of changes in the bacterial ecology of bovine mastitis with changes in the use of milking machines and antibacterial drugs. Acta vet. scand. 1994,35,363-369. - The results of mastitis bacteriology made by the National Veterinary and Food Research Institute in Finland during the past 50 years (1.15 million samples) are viewed in relation to simultaneous changes in dairy cow management. Although intensive preventive measures have been applied for decades, the prevalence of bovine mastitis has not decreased. Instead, pathogenic bacteria are becoming progressively less susceptible to the available therapy. In part this must be due to the emergence of antibiotic resistant strains of bacteria, but it seems that the bacterial spectrum has also changed. The incidence of Streptococcus agalactiae (group B streptococci) has decreased, while in contrast, the incidence of staphylococci, initially Staphylococcus aureus and later coagulase-negative staphylococci, has increased. Results suggest that external pressure, like changes in animal husbandry, including antimicrobial treatments and introduction of modern milking machines, act as selective forces on the bacterial species which cause bovine mastitis.
\end{abstract}

coagulase negative staphylococci; Streptococcus agalactiae; Staphylococcus aureus.

\section{Introduction}

Bovine mastitis is generally an infectious disease which causes serious economical losses to the dairy industry. Despite decades of intensive mastitis prevention its prevalence has not decreased. Currently about $45 \%$ of lactating cows in Finland have changes in milk indicating mastitis from one or more quarters (Anon. 1989). The attempts to decrease the prevalence of mastitis have been based mainly on preventive control measures, antibacterial therapy and culling of infected cows (Bramley \& Dodd 1984). The course of action is usually determined on the basis of economic factors, prognosis of the disease, and animal welfare. As symptoms and the prognosis of the disease vary according to the causative organism (Schalm et al. 1971), in mastitis treatment it is important to know the causative organism and its susceptibility to antibacterials.

Veterinarians treating mastitis cases are now facing the same problems as doctors working with human patients: pathogenic bacteria are becoming progressively less susceptible to the available therapy. In part this must be due to the emergence of antibiotic resistant strains of bacteria (Levy 1992, Seppälä et al. 1992, Pyörälä unpublished), but, especially in the case of mastitis, it seems that the bacterial spectrum can change (Erskine et al. 1988). In order to clarify the situation, we looked at the records of mastitis bacteriology made by the 


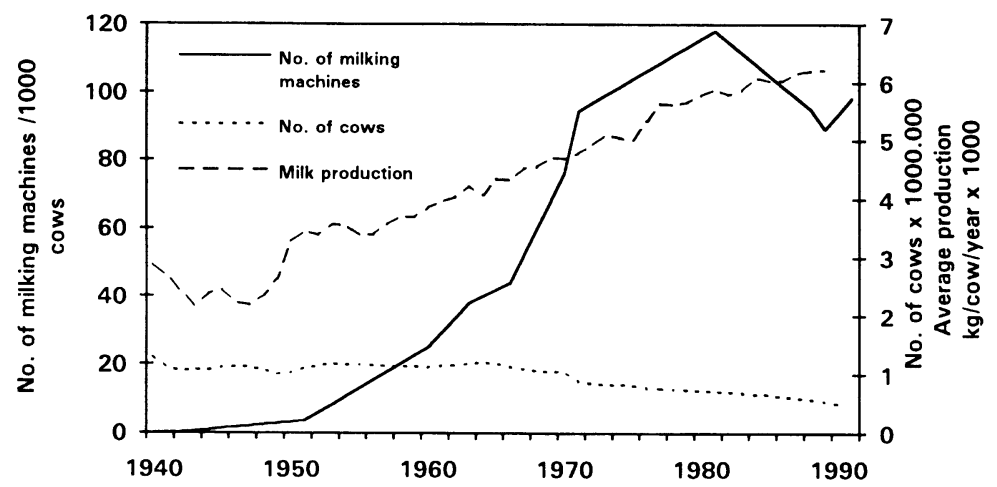

Figure 1. Number of cows, average milk yield and number of milking machines / 1000 cows in Finland from 1939 to 1990 (Anon. 1951 - 1990).

National Veterinary and Food Research Institute in Finland between 1939 and 1990. These results are viewed in relation to simultaneous changes in dairy cow management.

\section{Materials and methods}

In total, 1.15 million quarter milk samples were investigated using conventional bacteriological methods (Bergeys Manual Trust 1939 1974, Ehrström 1943, Klastrup \& Schmidt Madsen 1974) in the National Veterinary and Food Research Institute in Finland between 1939 and 1990. The basis for bacterial identification has remained largely unchanged, although methodologies have developed rapidly. The number of samples varied annually from 108 (1942) to 77,655 (1960).

Prior to 1974 , primary cultures of aseptically collected quarter milk samples were made by streaking $0.01 \mathrm{ml}$ milk on blood agar plates. Since 1974, blood agar was replaced with blood-aesculin. All samples which contained $>5$ colony forming units of the same bacterial species after $16-20 \mathrm{~h}$ incubation at $37^{\circ} \mathrm{C}$ were identified and recorded. Streptococcus agalactiae, however, was recorded even if the number of colonies was $<5$. Conventional bacteriological methods were used to differentiate bacterial species. Mastitis streptococci furthermore were differentiated using a combination of the CAMP-test, hydrolysis of esculin, hydrolysis of hippurate, sugar fermentation tests (inulin, raffinose and sorbitol) and Lancefield serogrouping. Staphylococci were previously differentiated from micrococci by testing the production of gas from glucose in an anaerobic environment. Since 1986, the lysostaphin test was used. Coagulase positive and coagulase negative staphylococci were differentiated by the haemolytic properties of the strains and by the coagulase test using horse or rabbit plasma.

\section{Results and discussion}

In modern animal husbandry the bacterial ecosystem on and within cows has become disturbed in many ways. During the last 50 years the number of dairy cows in the country has decreased from 1.2 million to 500,000 (Fig. 1). The cows were bred to produce more milk, neglecting disease resistance. Animal health was included in the breeding programme in 1986. Breeding and intensive feeding strategies have doubled the average milk yield (Fig. 1). Also the method of milking has progressed from hand milking to machine milking (Fig. 


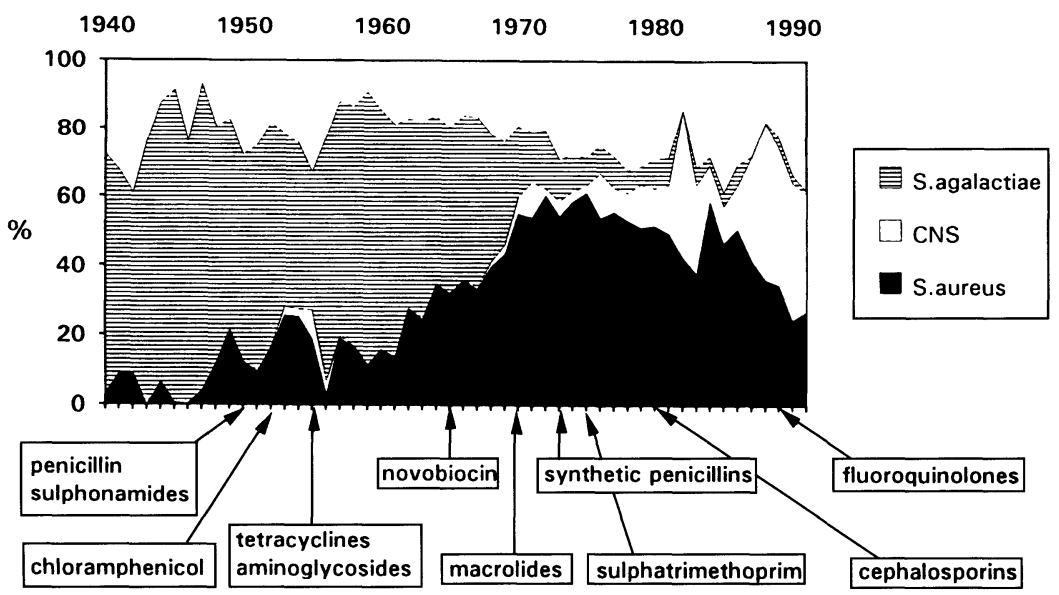

Figure 2. Percentage of Streptococcus agalactiae, Staphylococcus aureus and coagulase negative staphylococci (CNS) in all bovine milk samples with positive bacterial outcome, isolated between 1939 and 1990 at the National Veterinary and Food Research Institute in Finland (total no. of quarter milk samples 1.15 million). Arrows indicate the first year when a representative of each antimicrobial group was advertised for the first time in the Finnish Veterinary Journal.

1). The era of milking machines started in Finland in the 1960's. Straw bedding and an earth floor have been replaced with a concrete floor, which is more traumatizing to the skin. Antibacterials and post-milking teat dips became routine methods used in the fight against mastitis (Bramley \& Dodd 1984).

Compared to information from Central Europe and North America, our material is relatively low in gram-negative. The share of gram-negative has remained at about $9 \%$ (SD 5.9). It should be stressed that our material comes mainly from subclinical infections where persistent bacteria may become overrepresented as compared to studies on clinical disease. Infections caused by gram negative bacteria often are clinical and short lived.

Streptococcus agalactiae was the most important pathogen in the 1940's and 1950's (Fig. 2). The reservoir of the bacteria is thought to be the mucous membranes of infected animals, especially mastitic cows, and transmission is through direct contact with animals or via milking. Another known reservoir of $S$. agalactiae is the urogenital mucous membranes or lower gastrointestinal tract of humans ( $E d$ wards \& Baker 1990). Phenotypically, group B streptococci isolated from cows are often dissimilar from those isolated from human beings who have close contact with the infected cows (Jensen 1985). Genetically, group B streptococci strains of bovine and human origin with such an expected epidemiological relationship seem, however, to be identical as demonstrated by RIBO-typing ( $N$. E. Jensen, personal communication). During the hand milking era, transmission of $S$. agalactiae between the milker and the cow may have been frequent. Infection caused by $S$. agalactiae is generally chronic and subclinical, and the organism is extremely infective - as few as 10 viable streptococci may produce udder disease (Higgs et al. 1980). The undetected spread of the bacteria from animal to animal was probably the basis for its dominance in mastitis bacteriology. As $S$. agalactiae is read- 
ily eliminated with penicillin, the introduction of a centrally controlled formal scheme in 1943 to eradicate contagious mastitis caused by $S$. agalactiae, with constant monitoring of herds and treatment of infected animals, led almost to the disappearance of the organism from cows. Also, with the advent of machine milking, the reduced exposure of cows to the organism via milkers' hands may have prevented new infections.

Staphylococcus aureus replaced S. agalactiae as the most important mastitis pathogen during the 1960's (Fig. 2). The ability of S. aureus to survive in several habitats, particularly those that have been unsuitable for $S$. agalactiae, promoted $S$. aureus as a mastitis pathogen. The organism is abundant in the environment of animals (Matos et al. 1991), infections cannot effectively be treated with the old antibacterials (sulphonamides, penicillin, chloramphenicol, tetracyclines, etc.) (Craven 1987). Even though milking machines are capable of transferring all kinds of infective organisms, the transition from hand milking to milking machines especially seemed to be associated with staphylococcal mastitis. This relationship is evident in Fig. 1 \& 2.

Milking machines alter the balance between species of bacteria in at least 3 ways. Firstly, hand milking mimicked the suckling of calves and was less traumatising to the teat tissues than the machine milking of today (Hamann \& Stanitzke 1990). Secondly, during hand milking, the exposure time of the teat end to micro-organisms, which were spread by the hands of milkers (especially S. agalactiae), was more pronounced than during machine milking. Thirdly, it is known that the liners of milking machines may be responsible for contaminating the 4 or 5 cows milked following initial contamination of the liner (Grindal 1988). It may also be possible that liners collect milk constituents and microbes during milking that cannot be removed by routine washing with automatic equipment. The combination of artificial rubber, organic material and microbes constitutes the same kind of effect as an infected foreign body: commensal micro-organisms on the surface of liners, may adapt to growing in milk and becoming more virulent, for example, by developing a biofilm-type growth pattern under a slimy polysaccharide layer. When the bacteria are subsequently introduced into the udder, they can easily evade host defences, multiply and cause mastitis.

Both staphylococci and streptococci carry receptors that can attach to various tissue components (Chhatwal et al 1985, Espersen 1987), but not to living epithelium (Thomas et al. 1992). As $S$. aureus is a typical wound pathogen, and the milking machine may be a traumatizing device and infection carrier (Grindal 1988), this bacterium represents a special problem.

The reason why $S$. aureus has recently given way to coagulase negative staphylococci (CNS) is probably more complicated. In human beings, infections with CNS are usually linked with foreign bodies, and they become common with the increased use of artificial implants only a little earlier (Hedström 1986) than they became common in animals (Fig. 2). The most common CNS in human foreign body infections is Staphylococcus epidermidis. Staphylococcus epidermidis is also one of the most common isolates of CNS mastitis (Birgersson et al. 1992). Both $S$. aureus and CNS have the phenotypic plasticity needed for adaptation to foreign bodies (Dickinson \& Bisno 1989) such as milking machines. However, the mastitic infection caused by $S$. aureus is generally more severe than that caused by coagulase negative staphylococci such that the infection more often results in culling of the cow. Due to the differences seen in the severity of symptoms, CNS were earlier considered as minor pathogens (Timms \& Schultz 1987), 
and therefore the negative selection for $S$. $a u$ reus by culling infected cows during the last 10 years has not yet involved CNS. As CNS nowadays are more frequently isolated from acute mastitis cases, the attitude towards their importance as mastitic pathogens is changing (White et al. 1989). This is also the trend in human medicine (Archer 1990).

One selective force acting between $S$. aureus and CNS might be the antibiotic therapy practised in Finland. The introduction of sulphonamides and antibiotics into veterinary medicine started gradually during the 1940's. Despite the initial optimism, treatment of mastitis with intramammary infusions of sulphonamides and penicillin did not immediately become widespread in Finland. It is evident, however, that in the 1960 's, with the rise in the general standard of living, the use of antibacterials became more widespread. Typically, the early preparations consisted of broad spectrum antibiotic cocktails, which obviously were a result of commercial interests rather than emergence of multiresistant betalactamase producing bacteria. Generally, CNS can easily adapt to the use of antibacterials and become more resistant than $S$. aureus (Muhammad et al. 1993, Owens \& Watts 1988). Resistant strains arise, especially those resistant to synthetic penicillins, cephalosporins and sulphonamide-trimethoprim combinations (Archer 1990) to which most strains of $S$. aureus have remained susceptible. These antimicrobials emerged in the 1970's, and subsequent to their introduction the proportion of $S$. aureus in mastitis infections started to diminish. It seems possible that the careless use of antimicrobial cocktails in the past two decades has promoted the spread of CNS species. An example, on how the use of antimicrobials may influence bacterial species in mastitis, was reported by Ferns et al. (1991). Furthermore, Langlois et al. (1990) showed that Staphylococcus species from cows that had never been exposed to teat dips differed from those of cows that had been dipped routinely after milking.

These examples demonstrate clearly that the attempts to solve the mastitis problem have not had the ultimate desired effect: mastitiscausing bacteria have not been eradicated. On the contrary, they have redirected the bacterial ecology such that formerly unimportant bacterial species are replacing those displaced by current treatments. The prevalence of mastitis has not decreased as was expected. Recent awareness of the importance of CNS as pathogens will probably result in more strict measures for treating new infections caused by CNS. Whether this will leave a "bacteriological vacuum" that can be filled by other micro-organisms remains to be seen.

\section{References}

Anonymous: Ministry of Agriculture and Forestry: Utaretulehduksen torjunta. Mastitis Control. Helsinki, Report 19, 1989.

Anonymous: Central Statistical Office Statistical Yearbook of Finland. Goverment Printing Center, Helsinki, 1951 - 1990.

Archer GR: Staphylococcus epidermidis and other coagulase-negative staphylococci. In: GL Mandell, $R G$ Douglas \& JE Bennett (eds): Principles and practice of infectious diseases. Churchill and Livingstone, New York, 1990, p. 1511-1518.

Bergey's Manual Trust: Bergey's Manual of Determinative Bacteriology. Williams \& Wilkins, Baltimore, USA, 1939-1974.

Birgersson A, Jonsson P, Holmberg O: Species identification and some characteristics of coagulasenegative staphylococci isolated from bovine udders. Vet. Microbiol. 1992, 31, 181-189.

Bramley AJ, Dodd FH: Reviews of the progress of dairy science: mastitis control - progress and prospects. J. Dairy Res. 1984, 51, 481-512.

Chhatwal GS, Dutra IS, Blobel H: Fibrinogen Binding inhibits the fixation of the third Component of human complement on surface of groups A, B, C, and G Streptococci. Microbiol. Immunol. 1985, 29, 973-980.

Craven $N$ : Efficacy and financial value of antibiotic 
treatment of bovine clinical mastitis during lactation - a review. Br. vet. J. 1987, 143, 410-422.

Dickinson GM, Bisno AL: Infections associated with indwelling devices: infections related to extravascular devices. Antim. Agents Chemother. 1989, 33, 602-607.

Edwards MS, Baker CJ: Streptococcus agalactiae (Group B Streptococcus). In: Mandell GL, Douglas RG \& Bennett JE (eds). Principles and practice of infectious diseases. Churchill and Livingstone, New York, 1990, p. 1554-1563.

Ehrström W: Piirieläinlääkärit ja maidontarkastamojen taistelu tarttuvaa utaretulehdusta vastaan. (Distric veterinarians and the fight of milk control stations against contagious mastitis). Finnish Vet. J. 1943, 49, 353-362.

Erskine RJ, Eberhart RJ, Hutchinson LJ,Spencer SB, Campbell BS: Incidence and types of clinical mastitis in dairy herds with high and low somatic cell counts. J. Amer. vet. med. Ass., 1988, 192, 761-765.

Espersen $F$ : Interaction between human plasma proteins and cell wall components of Staphylococcus aureus. Dan. Med. Bull. 1987, 34, 59-69.

Ferns L, Dohoo I, Donald A: A case-control study of Nocardia mastitis in Nova Scotia dairy herds. Can. Vet. J. 1991, 32, 673-677.

Grindal RJ: The role of the milking machine in mastitis. Br. Vet. J. 1988, 144, 524-533.

Hedström $S \AA$ : Sepsis and septicaemia caused by coagulase-negative staphylococci. In: Mårdh P-A \& Schleifer KH (eds): Coagulase-Negative Staphylococci. Almqvist \& Wiksell International, Stockholm, 1986, p. 171-178.

Hamann J, Stanitzke U: Studies on pathogenesis of bovine mastitis by comparison of milking conditions as calf sucling, hand milking and machine milking; reactions of the tissue. Milchwissenschaft, 1990, 45, 632-637.

Higgs TM, Bramley AJ, Neave FK: Differences in intra-mammary pathogenity of 4 strains of Streptococcus dysgalactiae. J. Med. Microbiol. 1980, 13, 393-399.

Jensen $N E$ : Epidemiological aspects of human/animal interrelationship in GPS. Antibiot. Chemother. 1985, 35, 40-48.

Klastrup O, Schmidt Madsen P: Nordiske rekommendationer vedrørende mastitisunders $\emptyset$ gelser af kiertelprøver. (Nordic recommendations for investigation of quarter milk samples). Nord. Vet.Med., 1974, 26, 197-204.

Langlois BE, Parlindungan AK, Harmon RJ, Akers K:
Biochemical characteristics of Staphylococcus species of human and bovine origin. J. Food Protect. $1990,53,119-126$.

Levy $S B$ : The antibiotic paradox: How miracle drugs are destroying the miracle. Plenum Press, New York, 1992, 279 pp.

Matos JS, White DG, Harmon RJ, Langlois BE: Isolation of Staphylococcus aureus from sites other than the lactating mammary gland. J. Dairy Sci. 1991, 74, 1544-1549.

Muhammad G, Hoblet KH, Jackwood DJ, BechNielsen S, Smith KL: Interspecific conjugal transfer of antibiotic resistance among staphylococci isolated from bovine mammary gland. Amer. J. vet. Res. 1993, 54, 1432-1440.

Owens WE, Watts JL: Antimicrobial susceptibility and B-lactamase testing of staphylococci isolated from dairy herds. J. Dairy Sci. 1988, 71, 19341939.

Schalm OW, Carroll EJ, Jain NC: Bovine mastitis. Lea \& Febiger, Philadelphia, 1971, 360 pp.

Seppälä H, Nissinen A, Järvinen $H$, Huovinen $S$, Henriksson T, Herva E, Holm SE, Jahkola $M$, Katila M-L, Klaukka T, Kontiainen S, Liimatainen $O$, Oinonen S, Passi-Metsomaa L, Huovinen $P$ : Resistance to erythromycin in group A streptococci. N. Engl. J. Med. 1992, 32, 292-297.

Timms LL, Schultz LH: Dynamics and significance of coagulase-negative staphylococcal intramammary infections. J. Dairy Sci. 1987, 70, 2648-2657.

Thomas LH, Leigh JA, Bland AP, Cook RS: Adherence and colonization by bacterial pathogens in explant cultures of bovine mammary tissue. Vet. Res. Commun. 1992, 16, 87-96.

White DG, Harmon RJ, Matos JES, Langlois BE: Isolation and identification of coagulase-negative Staphylococcus species from bovine body sites and streak canals of nulliparous heifers. J. Dairy Sci. 1989, 72, 1886-1892.

\section{Sammanfattning}

Sambandet mellan förändringar $i$ bakterie ekologi vid bovin mastit och förändringar $i$ användandet av mjölkningsmaskiner och antibakteriella preparat.

Resultaten av mastit bakteriologi, som Anstalten för Veterinärmedicin och Livsmedel har samlat in under en period på 50 år har granskats genom att jämföra samtida förändningar inom kreaturskötseln. Mastit prevalensen har inte minskat trots att man i flere decennier utfört preventiva åtgärder. De patogena 
bakterierna har däremot blivit mindre känsliga för den använda terapin. Detta kan delvis bero på att det utvecklats antibiotikaresistentta stammar, men även bakteriespektret ser ut att ha förändrats. $S$. $a g$ alactiaes andel har minskat samtidigt som stafylokockernas andel ökat, först $S$. aureus och senare de koagulasnegativa stafylokockerna. Resultaten antyder att yttre faktorer, tex. förändringar $i$ kreaturskötsel, inkluderande antibiotika och användandet av mjölkningsmaskiner, skulle vara komponenter som förändrat spektret av mastit förorsakande bakterier.

(Received March 24, 1994; accepted August 19, 1994).

Reprints may be requested from: V. Myllys, Department of Food Hygiene, National Veterinary and Food Research Institute, Box 368, SF00231 Helsinki, Finland. 